\title{
Analisis Motivasi Kerja Perawat di Ruang Rawat Inap RS PKU Muhammadiyah Yogyakarta Unit II
}

\author{
Imram Radne Rimba Putri ${ }^{1}$, Elsye Maria Rosa ${ }^{2}$ \\ ${ }^{1}$ Sekolah Tinggi IImu Kesehatan Alma Ata Yogyakarta \\ Jalan Ringroad Barat Daya No 1 Tamantirto, Kasihan, Bantul, Yogyakarta \\ ${ }^{2}$ Program Studi Manajemen Rumah Sakit, Universitas Muhammadiyah Yogyakarta \\ Jalan Lingkar Selatan, Tamantirto, Kasihan, Bantul, Yogyakarta
}

\begin{abstract}
Abstrak
Perawat tidak hanya memberikan pelayanan yang memuaskan kepada pasien, tetapi mereka juga mengharapkan perhatian dari manajemen rumah sakit tempatnya bekerja yang dapat menumbuhkan motivasi kerja, agar tercipta kinerja secara optimal. Penelitian ini menggunakan metode mixed method research dengan model sequential explanory strategy. Data primer dikumpulkan melalui wawancara mendalam dan menggunakan kuesioner. Populasinya adalah semua perawat rawat inap di rumah sakit PKU Muhammadiyah unit II Yogyakarta, sampel sebanyak 51 perawat untuk menjawab kuesioner dan 4 perawat sebagai informan untuk wawancara, penelitian ini dilakukan sejak Juli 2014. Tujuan dari penelitian ini adalah untuk menganalisis motivasi kerja perawat yang ditinjau dengan tiga dimensi kebutuhan menurut teori motivasi ERG dari Alderfer. Hasil menunjukkan bahwa sebagian besar tingkat motivasi kerja perawat adalah tinggi yaitu sebanyak 49 (96,00\%) perawat dan 2 (4,00\%) orang perawat dengan tingkat motivasi rendah. Secara deskriptif sebagian besar motivasi kerja perawat ditinjau dari teori ERG berada dikategori tinggi. Kesimpulan tingkat motivasi kerja perawat ruang rawat inap di RS PKU Muhammadiyah Yogyakarta Unit Il dianalisis dengan tiga dimensi kebutuhan menurut teori motivasi ERG Alderfer adalah tinggi.
\end{abstract}

Kata Kunci: motivasi, perawat, teori ERG

\section{Analysis of Nurse's Work Motivation in Inpatient Wards at PKU Muhammadiyah Hospital of Yogyakarta Unit II}

\begin{abstract}
In hospital, the nurses not only give their service to patients, but they also expect the attention of the management of the hospital where she worked to motivate their work, in order to create optimal performance. This research employed a mixed method research with sequential explanory strategy model. Primary data were collected through in depth interview and used questionnaires. The population is all nurses in PKU Muhammadiyah hospital of Yogyakarta unit II, the sample is 51 nurses to answer the questionnaires and 4 nurses as the informants for the interview since July 2014. The purpose of this study was to analyze the motivation of nurses were reviewed by three dimensions according to the needs of Alderfer's ERG theory of motivation. The results showed that the majority of nurses work motivation level was as high as many as 49 nurses with a percentage $96.00 \%$ and 2 nurses with a percentage $4.00 \%$ of nurses with low motivation levels. In descriptive terms of work motivation nurses were categorized high in ERG theory. The conclusion was that the level of motivation of the cnurses the inpatient at ward PKU Muhammadiyah hospital of Yogyakarta unit II analyzed by three dimensional according to the needs of Alderfer's ERG theory of motivation is high.
\end{abstract}

Keywords: ERG theory, nurse, work motivation

Info Artikel:

Artikel dikirim pada 17 Juni 2015

Artikel diterima pada 18 Juni 2015 


\section{PENDAHULUAN}

Kualitas pelayanan di rumah sakit (RS) sangat dipengaruhi oleh banyak faktor, satu di antaranya adalah sumber daya manusia (SDM). Keadaan sumber daya yang sangat heterogen di rumah sakit perlu mendapat perhatian khusus, agar mempunyai pengaruh besar terhadap kualitas pelayanan RS. Pengelolaan sumber daya manusia yang baik apabila sumber daya manusia tersebut sudah dapat dimanfaatkan secara optimal dan mempunyai kerja yang bermutu(1). Perawat adalah salah satu sumber daya manusia di rumah sakit yang jumlahnya mendominasi tenaga kesehatan secara menyeluruh, juga penjalin kontak pertama dan terlama dengan pelanggan (pasien dan keluarganya). Pelayanan keperawatan merupakan bagian integral dari pelayanan kesehatan di rumah sakit, yang mempunyai posisi yang sangat strategis dalam upaya meningkatkan mutu pelayanan dan pemuasan konsumen yang datang ke rumah sakit(2).

Kemampuan perawat melakukan praktek profesional perlu dipertahankan, dikembangkan, dan ditingkatkan melalui manajemen SDM perawat yang konsisten disesuaikan dengan perkembangan ilmu pengetahuan dan teknologi. Pengembangan SDM digambarkan sebagai proses pengelolaan motivasi staf sehingga dapat bekerja secara produktif. $\mathrm{Hal}$ ini juga merupakan penghargaan bagi profesi keperawatan karena melalui manajemen SDM yang baik maka perawat mendapatkan kompensasi berupa penghargaan (compensatory reward) sesuai dengan apa yang telah dikerjakan(3). Hal ini merupakan salah satu stimulan yang dapat memotivasi perawat untuk bekerja dengan lebih giat dan lebih baik lagi.

Motivasi adalah dorongan dari dalam diri seseorang yang menyebabkan seseorang tersebut bertindak atau melakukan pekerjaan secara sadar. Seseorang yang bekerja tentu didasari oleh motivasi, tentu saja derajat motivasinya berbedabeda. Kinerjanya seseorang selain ditentukan oleh kemampuannya, juga sangat ditentukan oleh motivasi kerjanya. Orang yang melakukan pekerjaan dengan motivasi yang rendah tidak akan dapat melakukan tugasnya semaksimal kemampuan dan kesanggupannya, sebaliknya dengan motivasi yang tinggi seseorang dapat melakukan pekerjaannya semaksimal kemampuannya(4). Motivasi kerja perawat yang tinggi akan meningkatkan kinerja perawat sehingga setiap tugas akan dilaksanakan secara baik(5).

Melihat pentingnya motivasi kerja, berbagai teori mengenai motivasi kerja diperkenalkan dalam memahami perilaku manusia. Teori-teori motivasi dibagi menjadi dua bagian yaitu; pertama teori kepuasan yang terdiri dari; teori hierarki kebutuhan oleh Abraham $\mathrm{H}$. Maslow, teori dua faktor oleh Frederick Herzberg, teori $X$ dan $Y$ oleh Douglas Mc Gregor, teori kebutuhan yang dipelajari oleh David McClelland dan teori ERG oleh Clayton P Alderfer. Kedua Teori motivasi proses terdiri dari teori penguatan oleh Skinner, teori harapan oleh Vroom, teori keadilan oleh Adams dan teori penetapan tujuan oleh Locke(3).

Penelitian ini terfokus pada Teori ERG oleh Clayton Alderfer yang dianggap paling empiris terkait teori motivasi tentang kebutuhan manusia. Menurut Clayton Alderfer dalam teori ERG nya, motivasi itu berkaitan dengan kebutuhan pokok manusia yang terdiri dari existence needs atau kebutuhan akan keberadaan, relatedness needs atau kebutuhan berhubungan dan growth needs atau kebutuhan untuk berkembang. Dalam meningkatkan motivasi kerja seseorang maka ketiga kebutuhan pokok manusia tersebut sedapat mungkin terpenuhi ${ }^{6}$. Pemenuhan kebutuhan perawat yang sesuai harapannya juga menjadi strategi berbagai rumah sakit untuk membuat perawat termotivasi untuk betah bekerja di suatu rumah sakit yang sering dikenal sebagai istilah magnet hospital(1).

Hasil studi pendahuluan di RS PKU Muhammadiyah Yogyakarta Unit II terdapat pernyataan dari perawat bahwa belum terpenuhinya kebutuhan perawat seperti belum sesuainya gaji, fasilitas RS yang sesuai dengan harapan perawat, yang dikawatirkan akan berpengaruh pada tingkat motivasi yang rendah. Pentingnya motivasi perawat merupakan permasalahan yang harus diperhatikan manajemen keperawatan RS PKU Yogyakarta unit II karena tingkat motivasi perawat sangat mempengaruhi kinerja perawat. Kinerja perawat akan mempengaruhi kualitas pelayanan yang nantinya akan berdampak minat masyarakat untuk menggunakan fasilitas rawat inap RS PKU Yogyakarta unit II. Oleh karena itu perlu diketahui bagaimana motivasi kerja perawat di ruang rawat inap di RS PKU Muhammadiyah Yogyakarta unit II.

\section{BAHAN DAN METODE}

Penelitian ini menggunakan metode mixed method research dengan model sequential explanory strategy. Data primer dikumpulkan melalui wawancara mendalam dan menggunakan kuesioner, Kuesioner yang terdiri dari 3 demensi dengan total 45 item, format jawaban dari kuesioner ini menggunakan skala likert. Pengukuran variabel motivasi kerja menggunakan metode pengisian kuesioner berupa skala motivasi kerja yang disebut work motivation scale (WMS) 
yang diadopsi dari Arnolds dan Boshoff dan telah dimodifikasi oleh peneliti sebelumnya Ruswanti(7). Kuesioner ini sudah diuji validitas dan reliabilitas. Populasinya adalah semua perawat rawat inap di rumah sakit PKU Muhammadiyah unit II Yogyakarta, sampel adalah 51 perawat untuk menjawab kuesioner dan 4 perawat sebagai informan untuk wawancara, penelitian ini dilakukan sejak Juli 2014.

\section{HASIL DAN BAHASAN}

Analisis Data Penelitian Analisis Motivasi Kerja Perawat di Ruang Rawat Inap di RS PKU Muhammadiyah Yogyakarta unit II.

\section{Analisis terhadap Variabel Existence}

Analisis terhadap variabel existence berdasarkan aspek imbalan, kondisi kerja, dan variabel existence hasilnya dapat dilihat pada Tabel 1.

Tabel 1. Data Kategori Tingkat Motivasi Kerja Perawat Berdasarkan Variabel Existence

\begin{tabular}{lcc}
\hline Variabel Existence & $\mathbf{f}$ & $\%$ \\
\hline Aspek imbalan & & \\
$\quad$ Tinggi & 48 & 94,20 \\
Rendah & 3 & 5,80 \\
Aspek kodisi kerja & & \\
$\quad$ Tinggi & 45 & 88,20 \\
$\quad$ Rendah & 6 & 11,80 \\
Variabel existence & & \\
$\quad$ Tinggi & 47 & 92,20 \\
$\quad$ Rendah & 4 & 7,80 \\
Total & 51 & 100 \\
\hline
\end{tabular}

Sumber: Data Primer Tahun 2014

Berdasarkan Tabel 1, hasil penelitian ini menunjukkan kategori tingkat motivasi kerja tenaga keperawatan di ruang rawat inap RS PKU Muhammadiyah Yogyakarta unit II ditinjau dari pemenuhan pemberian imbalan, menunjukkan bahwa sebagian besar tingkat motivasi kerja perawat adalah tinggi yaitu sebanyak 48 perawat dengan persentase $94,20 \%$ dan 3 perawat dengan persentase 5,80\% dengan motivasi rendah. Rendahnya motivasi perawat bisa terjadi karena tidak terpenuhinya kebutuhan sesuai harapan perawat, hal ini didukung berdasarkan pengakuan dari semua informan, tidak semua aspek dalam variabel imbalan dirasa sesuai dengan yang mereka harapkan, yaitu pada aspek gaji, tunjangan kesehatan dan seragam perawat.

Aspek kebutuhan memberikan pengaruh besar dalam mendorong motivasi bekerja. Hal ini terjadi karena kesadaran dari setiap responden tentang apa yang menjadi kebutuhannya saat ini. Aspek kebutuhan yaitu suatu rasa dari seseorang terkait dengan apa yang menjadi kebutuhannya. Perawat sebagai individu tentunya ingin memenuhi kebutuhannya dalam segala aspek. Kebutuhan ini meliputi kebutuhan mendasar (exsistence), kebutuhan keterkaitan/hubungan (relatedness) dan kebutuhan untuk berkembang atau aktualisasi diri (growth)(6).

Ditinjau dari aspek kondisi kerja menunjukkan bahwa sebagian besar tingkat motivasi kerja perawat adalah tinggi yaitu sebanyak 45 perawat dengan persentase $88,20 \%$ dan 6 orang perawat atau $11,80 \%$ perawat dengan tingkat motivasi rendah. Tingginya hasil tersebut didukung dengan hasil kutipan wawancara dengan informan yang mengatakan, sebagai berikut: "...tempat kerja bersih dan nyaman...". Namun rendahnya hasil motivasi didukung dari wawancara dengan keempat informan, diketahui bahwa masih terdapat beberapa ketidak sesuaian atau ketidak puasan perawat terkait kondisi tempat kerjanya, seperti hasil wawancara berikut: “...tapi kalau pas AC nya mati pengap di dalam, jadi mending keluar lah sekali-kali...". Hal tersebut mendukung hasil penelitian yang menyatakan bahwa masih juga terdapat beberapa perawat yang motivasinya rendah, rendahnya motivasi perawat bisa terjadi karena tidak terpenuhinya kebutuhan sesuai harapan perawat, yaitu mengenai sirkulasi udara dan kamar mandi, seperti hasil wawancara berikut: "...saya tidak puas karena kamar mandi untuk perawat, dibangsal saya belum punya ...". Begitu pula mengenai kondisi tempat kerja terkait kamar mandi, mengatakan: “...kamar mandinya,,, bersihinnya itu kadang sehari iya, kadang cuma dua hari sekali”.

Hasil penelitian ini menunjukkan kategori tingkat motivasi kerja tenaga keperawatan di ruang rawat inap RS PKU Muhammadiyah Yogyakarta unit II ditinjau dari kebutuhan mendasar (exsistence) menunjukkan bahwa sebagian besar tingkat motivasi kerja perawat adalah tinggi yaitu sebanyak 47 perawat dengan persentase $92,20 \%$ dan 4 orang perawat atau $7,80 \%$ perawat dengan tingkat motivasi rendah. Kebutuhan tentang eksistensi berkaitan dengan pemuasan kebutuhan materi mendasar yang diperlukan dalam mempertahankan eksistensi seseorang. Dalam penelitian ini kebutuhan eksistensi mencakup kebutuhan akan imbalan dan kondisi lingkungan kerja.

Apabila kekurang puasan perawat setiap aspek dalam variabel eksistensi dapat dipenuhi, memungkinkan peningkatan tingkat motivasi kerja perawat, yang diharapkan dapat meningkatkan pula kualitas kerja perawat. Hasil analisis-analisis diatas membuktikan bahwa faktor imbalan yang diberikan rumah sakit dan kondisi lingkungan pekerjaan memiliki pengaruh terhadap motivasi kerja perawat, yang mampu mendorong motivasi untuk bekerja lebih baik lagi(8). 


\section{Analisis Terhadap Variabel Relatedness}

Analisis terhadap variabel relatedness berdasarkan aspek hubungan dengan atasan, hubungan dengan rekan kerja, dan variabel relatedness hasilnya dapat dilihat pada Tabel 2.

Tabel 2. Data Kategori Tingkat Motivasi Kerja Perawat Berdasarkan Variabel Relatedness

\begin{tabular}{lcc}
\hline Variabel Relatedness & f & $\%$ \\
\hline Aspek Hubungan Dengan Atasan & & \\
$\quad$ Tinggi & 49 & 96,0 \\
$\quad$ Rendah & 2 & 4,0 \\
Aspek hubungan dengan rekan kerja & & \\
$\quad$ Tinggi & 47 & 92,20 \\
$\quad$ Rendah & 4 & 7,80 \\
Variabel relatedness & & \\
$\quad$ Tinggi & 48 & 94,10 \\
$\quad$ Rendah & 3 & 5,90 \\
Total & 51 & 100 \\
\hline
\end{tabular}

Sumber: Data Primer Tahun 2014

Berdasarkan hasil Tabel 2, motivasi kerja perawat di ruang rawat inap RS PKU Muhammadiyah Yogyakarta Unit II ditinjau dari aspek hubungan dengan atasan menunjukkan bahwa sebagian besar tingkat motivasi kerja perawat adalah tinggi yaitu sebanyak 49 perawat dengan persentase $96,0 \%$ dan 2 orang perawat atau $4,0 \%$ perawat dengan tingkat motivasi rendah. Hasil penelitian ini menunjukan bahwa tingkat motivasi kerja perawat dalam berhubungan dengan atasan dalam ketegori tinggi. Apabila ditemukan masalah diberikan petunjuk atau bantuan yang bersifat langsung mengatasinya. Motivasi yang dimiliki perawat tidak terlepas dari peran atasannya. Motivasi setiap karyawan berbeda-beda. Jika ingin memaksimalkan motivasi bagi karyawan, kuncinya adalah memotivasi secara fleksibel, antara lain dengan mendesain jadwal kerja, rencana penggajian atau pemberian insentif, manfaat dan menata lingkungan tempat kerja seperti menata peralatan kerja $^{9}$. Kemampuan memotivasi karyawan merupakan keterampilan manajerial yang harus dikuasai oleh seorang pimpinan atau atasan. Secara psikologis, atasan tidak mungkin mampu mempengaruhi motivasi bawahannya tanpa sebelumnya memahami apa yang dibutuhkan oleh karyawannya. Dengan memahami peranan penting motivasi karyawan akan mempermudah pimpinan mengharapkan prestasi dan kepuasan kerja karyawan(10).

Motivasi kerja perawat ditinjau dari aspek hubungan dengan rekan kerja menunjukkan bahwa sebagian besar tingkat motivasi kerja perawat adalah tinggi yaitu sebanyak 47 perawat dengan persentase $92,20 \%$ dan 4 orang perawat atau $7,80 \%$ perawat dengan tingkat motivasi rendah. Aspek hubungan dengan rekan kerja yaitu perasaan individu/perawat terhadap sebuah bentuk kerja sama atau interaksi secara imbal balik antara individu dengan teman kerja dan atasan. Hubungan ini dapat bersifat sosial maupun sosioteknikal (yang berhubungan dengan pekerjaan)(6). Pada hasil wawancara juga diketahui bagaimana cara perawat dengan rekan kerjanya dalam penyelesaian masalah atau konflik.

Hasil analisis terhadap variabel relatedness diperoleh bahwa motivasi kerja perawat diruang rawat inap RS PKU Muhammadiyah Yogyakarta Unit II ditinjau dari variabel Relatedness menunjukkan bahwa sebagian besar tingkat motivasi kerja perawat adalah tinggi yaitu sebanyak 48 perawat dengan persentase $94,10 \%$ dan 3 orang perawat atau $5,90 \%$ perawat dengan tingkat motivasi rendah. Kebutuhan keterkaitan (relatedness) yaitu berhubungan dengan pentingnya pemeliharaan hubungan interpersonal yang dalam teori ERG tergambar pada kebutuhan sosial seperti hubungan dengan rekan kerja dan hubungan dengan atasan(6).

\section{Analisis Terhadap Variabel Growth}

Analisis terhadap variabel growth berdasarkan aspek kesempatan berkembang, penghargaan, dan variabel growth hasilnya dapat dilihat pada Tabel 3.

Tabel 3. Data Kategori Tingkat Motivasi Kerja Perawat Berdasarkan Variabel Growth

\begin{tabular}{lcc}
\hline \multicolumn{1}{c}{ Variabel Growth } & $\mathbf{f}$ & $\%$ \\
\hline Aspek kesempatan berkembang & & \\
$\quad$ Tinggi & 44 & 86,20 \\
$\quad$ Rendah & 7 & 13,80 \\
Aspek penghargaan & & \\
$\quad$ Tinggi & 47 & 92,20 \\
$\quad$ Rendah & 4 & 7,80 \\
Variabel growth & & \\
$\quad$ Tinggi & 45 & 88,20 \\
$\quad$ Rendah & 6 & 11,80 \\
Total & 51 & 100 \\
\hline
\end{tabular}

Sumber: Data Primer Tahun 2014

Berdasarkan hasil Tabel 3, motivasi kerja perawat di ruang rawat inap RS PKU Muhammadiyah Yogyakarta Unit II ditinjau dari aspek kesempatan berkembang menunjukkan bahwa sebagian besar tingkat motivasi kerja perawat adalah tinggi yaitu sebanyak 44 perawat dengan persentase $86,20 \%$ dan 7 orang perawat atau $13,80 \%$ perawat dengan tingkat motivasi rendah. Motivasi kerja perawat ditinjau dari aspek penghargaan menunjukkan bahwa sebagian besar tingkat motivasi kerja perawat adalah tinggi yaitu sebanyak 47 perawat dengan persentase 
$92,20 \%$ dan 4 orang perawat atau $7,80 \%$ perawat dengan tingkat motivasi rendah.

Pemberian penghargaan dan promosi dapat meningkatkan ikatan kerja sama, kepuasan kerja, pengadaaan efektif, motivasi, stabilisasi dan disiplin karyawan $^{5}$. Dari pendapat tersebut, bahwa penting adanya kebijakan mengenai promosi dan penghargan kepada karyawan, sebagai motivasi dalam bekerja untuk mencapai kepuasan kerja yang diharapkan. Hal ini sesuai dengan penelitian terdahulu yang menyatakan faktor penghargaan karir mempengaruhi motivasi kerja perawat secara signifikan(11). Melalui penghargaan yang sesuai dengan apa yang telah dikerjakan merupakan salah satu stimulant yang dapat memotivasi perawat untuk bekerja dengan lebih giat dan lebih baik lagi(12).

Hasil analisis terhadap variabel growth diperoleh bahwa motivasi kerja perawat di ruang rawat inap RS PKU Muhammadiyah Yogyakarta Unit II ditinjau dari variabel Growth menunjukkan bahwa sebagian besar tingkat motivasi kerja perawat adalah tinggi yaitu sebanyak 45 perawat dengan persentase $88,20 \%$ dan 6 orang perawat atau $11,80 \%$ perawat dengan tingkat motivasi rendah. Kebutuhan untuk berkembang atau aktualisasi diri (Growth) merupakan kebutuhan untuk berkembang secara intelektual, yang berarti identik dengan kebutuhan aktualisasi diri seperti kebutuhan untuk berkembang, berupa status yang jelas, penghargaan, kreatifitas, kesempatan untuk berpendidikan, mendapat pelatihan dan promosi.

Tabel 4. Data Kategori Tingkat Motivasi Kerja Perawat berdasarkan Variabel ERG

\begin{tabular}{lcc}
\hline Kategori & f & $\%$ \\
\hline Tinggi & 49 & 96,0 \\
Rendah & 2 & 4,0 \\
Total & 51 & 100 \\
\hline
\end{tabular}

Sumber: Data Primer Tahun 2014

Berdasarkan hasil Tabel 4, motivasi kerja perawat di ruang rawat inap RS PKU Muhammadiyah Yogyakarta Unit II ditinjau dari seluruh variabel ERG menunjukkan bahwa sebagian besar tingkat motivasi kerja perawat adalah tinggi yaitu sebanyak 49 perawat dengan persentase $96,0 \%$ dan 2 orang perawat atau $4,0 \%$ perawat dengan tingkat motivasi rendah.

Kualitas pelayanan rumah sakit dipengaruhi oleh banyak faktor, tetapi faktor sumber daya manusia merupakan faktor yang paling penting. Agar sumber daya manusia mempunyai pengaruh konstruktif terhadap kualitas pelayanan rumah sakit, maka harus dikelola dengan baik. Salah satu caranya dengan meneliti tingkat motivasi kerja sumber daya manusianya yang sangat berpengaruh pada kinerja.
Penelitian ini menjawab hal tersebut. Tingkat motivasi kerja menurut masing-masing variabel yang dipakai pada penelitian ini yang merupakan uraian dari variabel tiga dimensi motivasi kerja dari teori ERG Alderfer, motivasi kerja perawat diruang rawat inap RS PKU Muhammadiyah Yogyakarta Unit II ditinjau dari seluruh variabel ERG menunjukkan bahwa sebagian besar tingkat motivasi kerja perawat adalah tinggi.

Pengelolaan tenaga perawat perlu mendapat perhatian dari pimpinan rumah sakit baik dalam pelaksanaan tugas profesi maupun yang berkaitan dengan administrasi kepegawaian. Disamping itu pihak manajemen semestinya memberikan dukungan yang kuat kepada tenaga dokter dan perawat dalam melaksanakan tugasnya termasuk urusan kepegawaian agar mereka dapat lebih tenang dan fokus kepada pasien(9). Suatu hal yang perlu diperhatikan adalah motivasi kerja karena dapat mempengaruhi produktivitas dan prestasi kerja seseorang. Perawat dirumah sakit tidak hanya memberikan pelayanan kepada pasien tetapi mereka juga mengharapkan pelayanan dari pihak manajemen rumah sakit agar apa yang menjadi haknya dapat diterima dengan baik(13).

Dalam penelitian ini angka motivasi kerja yang tinggi di RS PKU Muhammadiyah Yogyakarta Unit II tentunya jangan sampai membuat pihak manajerial lengah dan harus tetap menjamin dan bahkan meningkatkan produktivitas kerja, hingga pada akhirnya akan meningkatkan kepuasan klien atau pasien. $\mathrm{Hal}$ ini didukung dengan penelitian yang dilakukan sebelumnya, yang menjelaskan bahwa berbagai macam faktor, antara lain pemimpin, imbalan, teman kerja, lingkungan kerja, pekerjaan sendiri, pendapatan dan tingkat pendidikan. Faktor-faktor tersebut akan berdampak terhadap produktifitas kerja, komitmen dalam organisasi, dan motivasi kerja(14).

Seseorang termotivasi bekerja karena untuk memenuhi kebutuhannya, kebutuhan-kebutuhan tersebut terangkum dalam teori ERG, apabila kebutuhan tidak terpenuhi akan mempengaruhi kinerja perawat. Tetapi apabila terpenuhi maka cenderung mempertahankan dan meningkatkan kinerjanya. Dapat dikatakan, motivasi kerja seseorang tergantung pemenuhan kebutuhannya(6). Motivasi kerja merupakan elemen yang tidak dapat dikesampingkan dalam suatu organisasi, oleh karena ini diperlukan faktor untuk menumbuhkan dan mendorong motivasi kerja. Karena, semakin tinggi motivasi kerja seseorang, dapat meningkatkan kinerjanya, dan sebaliknya, semakin baik kinerja perawat maka motivasi kerja juga akan semakin meningkat. Walau pada dasarnya setiap individu memiliki tingkat motivasi yang berbeda-beda sesuai 
dengan sistem nilai-nilai yang berlaku pada dirinya. Semakin banyak aspek-aspek dalam pekerjaan sesuai dengan keinginan individu tersebut, maka semakin tinggi motivasi dirasakan dan sebaliknya(1).

\section{Analisis Data Berdasarkan Hasil Wawancara}

Berdasarkan hasil wawancara dengan para informan terkait tentang tiga variabel kebutuhan dari teori motivasi ERG yaitu variabel existence, relatedness dan growth dapat disimpulkan bahwa, terkait dengan variabel existence, masih adanya ketidakpuasan perawat terkait gaji yang tidak sesuai beban kerja dan tidak adanya jasa profesi. Pemberian gaji yang belum sesuai dengan keinginan karyawan, atau pemberian gaji yang belum mencukupi kebutuhan karyawan. Pada fasilitas seragam dapat menjadi masukan untuk pihak manajerial dalam memperhatikan kenyamanan kain seragam dan jumlah seragamnya dan memperhatikan kondisi tempat kerja untuk perawat terkait sirkulasi udara di ruangan dan kamar mandi. Tetapi untuk kondisi tempat kerja yang aman dan nyaman, seluruh responden setuju kalau sudah bagus, dan mereka juga puas, hanya perlu ditingkatkan lagi. Terdapat jaminan kecelakaan kerja berupa Jamsostek dan Jaminan kesehatan berupa Takaful, tetapi dirasa hanya sebatas cukup puas, karena terkait pembayaran dari pihak rumah sakit yang tidak menanggung semua biaya pengobatan dan tidak bisa mengajukan klaim pembiayaan penuh ke RS PKU jika karyawan yang sakit dirawat di rumah sakit lain. Adapun reduksi data-coding hasil wawancara yang dilakukan pada 4 informan dapat dilihat pada Tabel 5.
Hasil penelitian ini mendukung penelitian terdahulu yang dilakukan oleh Fauzi, yang menunjukkan bahwa gaji berpengaruh terhadap motivasi kerja. Semakin besar pemberian gaji atau insentif semakin tinggi motivasi kerja. Pemberian gaji mempengaruhi motivasi kerja, karena dengan gaji yang tinggi dapat memotivasi untuk bekerja lebih baik(14).

Huston berpendapat bahwa uang sesungguhnya dapat menjadi motivator(15). Seperti yang ditunjukkan oleh orang yang bekerja pada jam-jam yang sulit yang sesungguhnya tidak mereka nikmati. Pemberian gaji yang belum sesuai dengan keinginan karyawan, atau pemberian gaji yang belum mencukupi kebutuhan karyawan dapat menimbulkan kekawatiran finansial pada karyawan sehingga menyebabkan stress yang bersifat off the job, yang tentunya akan mempengaruhi motivasi dan produktifitas kerja(16).

Menurut Winardi, apabila terjadi ketidak sesuaian dan ketidakpuasan dalam pemenuhan kebutuhan, akan terjadi tendensi bagi orang yang bersangkutan untuk melaksanakan perilaku penyesuaian (coping behavior)(17). Hal tersebut berupa upaya sebuah upaya untuk mengatasi penghalang tersebut dengan jalan pemecahan masalah secara uji coba, orang yang bersangkutan dapat mencoba aneka macam perilaku guna menemukan sebuah perilaku yang akan mencapai tujuan yang diinginkan atau akan mengurangi ketegangan atau masalah yang timbul.

Apabila kekurang puasan perawat setiap aspek dalam variabel eksistensi dapat dipenuhi, memungkinkan peningkatan tingkat motivasi kerja perawat, yang diharapkan dapat meningkatkan pula kualitas kerja perawat. Hasil analisis-analisis di atas

Tabel 5. Rangkuman Hasil Wawancara Tentang Variabel Existence terhadap Perawat Ruang Rawat Inap di RS PKU Muhammadiyah Yogyakarta Unit II

\begin{tabular}{|c|c|}
\hline $\begin{array}{l}\text { Kata kunci } \\
\text { pertanyaan }\end{array}$ & Coding \\
\hline $\begin{array}{l}\text { Variabel } \\
\text { Existence }\end{array}$ & $\begin{array}{l}\text { Pemberian gaji yang tepat waktu. } \\
\text { Tidak adanya jasa profesi untuk perawat } \mathrm{S} 1 \text {. } \\
\text { Gaji hanya cukup untuk memenuhi kebutuhan sehari-hari. } \\
\text { Gaji tidak sesuai dengan beban kerja. } \\
\text { Relatif cukup untuk yang belum menikah. } \\
\text { Tempat kerja yang dinilai bersih dan nyaman. } \\
\text { Hanya tidak adanya fasilitas kamar mandi khusus perawat di bangsal Wardah. } \\
\text { Proses pembersihan kamar mandi perawat, yang kadang dibersihkan tidak setiap hari tapi dua hari } \\
\text { sekali. } \\
\text { Fasilitas seragam dirasa masih kurang untuk jumlah baju dan jilbab perawat. } \\
\text { Fasilitas seragam yang diberikan RS dirasa kain seragamnya tidak nyaman dipakai karena terasa panas } \\
\text { dan gatel dikulit } \\
\text { Kurang puas dengan fasilitas olah raga senam yang perawat harus membayar kalau ingin mengikuti. } \\
\text { Kondisi lingkungan kerja hanya di sirkulasi udara yang belum maksimal, jadi pengap jika AC diruangan } \\
\text { mati. } \\
\text { RS mempunyai tunjangan kesehatan yang disebut Takaful dan ada jaminan kecelakaan kerja Jamsostek. } \\
\text { hanya belum puas dengan kebijakan Takaful yang berubah-ubah sesuai dengan keungan RS dan belum } \\
\text { ditanggung semua untuk biaya pengobatan perawat yang sakit. }\end{array}$ \\
\hline
\end{tabular}

Sumber: Data Primer Tahun 2014 
membuktikan bahwa faktor imbalan yang diberikan rumah sakit dan kondisi lingkungan pekerjaan memiliki pengaruh terhadap motivasi kerja perawat, yang mampu mendorong motivasi untuk bekerja lebih baik lagi.

Terkait dengan variabel relatedness berdasatkan Tabel 6 dapat disimpulkan bahwa hubungan perawat dengan rekan kerjanya baik, terjalin hubungan kekeluargaan, saling kolaborasi dan kebersamaan yang saling toleran dan menghormati. Jika ada masalah diselesaikan secepatnya dan bersamasama. Hubungan perawat dengan atasannya baik dan tidak pernah ada masalah, terjalin komunikasi yang baik. Jika ada masalah diselesaikan secepatnya dan bersama-sama dengan mengadakan rapat kecil setiap bulan sekali di bangsal yang dipimpin oleh kepala ruang dan rapat besar pada setiap hari selasa yang terdiri dari para direksi rumah sakit.

Seperti yang dijelaskan oleh Perdana bahwa apabila ada karyawan yang tidak saling cocok dipasangkan dalam satu tim, maka dapat mengganggu kinerja mereka. Setelah tim tersebut dirombak anggotanya, ternyata kinerja mereka malah sama-sama meningkat(16). Manfaat hubungan antar pribadi manusia dalam organisasi adalah pimpinan dapat memecahkan masalah bersama pegawai baik masalah yang menyangkut individu maupun masalah umum organisasi, sehingga dapat menggairahkan kembali semangat kerja dan meningkatkan produktifitas.

Hubungan yang baik dan tidak adanya konflik dengan rekan kerja dapat mencegah terjadinya stress pada karyawan. Selain itu hubungan yang baik antara sesama perawat, antara tenaga kesehatan yang lain dan didasari dengan rasa percaya, saling menghargai, saling berbagi dalam pengetahuan, skill, dan rasa saling membantu akan mengoptimalkan dalam perawatan terhadap pasien. Masroor menjelaskan bahwa faktor teman kerja seperti memberi dukungan antara sesama perawat, kerja sama antara satu dengan yang lain, dan tidak mementingkan diri sendiri, merupakan hal- hal yang mempengaruhi karyawan dalam motivasi kerja(18). Hal ini sesuai dengan penelitian sebelumnya oleh Budiman yaitu terdapat hubungan antara aspek sesama pekerja dengan motivasi kerja(19). Semakin baik hubungan dalam kelompok kerja maka akan memberikan motivasi bagi karyawan. Menurut Hezberg, faktor yang mempengaruhi suatu motivasi kerja seseorang yaitu kelompok kerja yang mempunyai arti tentang kerjasama dan keeratan hubungan antara teman sekerja dalam kelompok(20).

Aspek hubungan dengan atasan yaitu perasaan individu/perawat terhadap pengawasan yang diterima dari atasannya. Motivasi yang dimiliki perawat tidak terlepas dari peran atasannya. Hubungan yang baik dan tidak adanya konflik dengan atasan dapat mencegah terjadinya stress pada karyawan 21).

Terkait dengan variabel growth berdasarkan Tabel 7 dapat disimpulkan bahwa dalam penelitian ini keseluruhan informan menjawab sudah puas terhadap kebijakan manajemen RS terkait dengan pemberian kesempatan untuk mengikuti pelatihan yang mereka anggap sudah merata untuk pemilihan peserta pelatihannya yang bergantian dan rumah sakit juga mengikut sertakan perawat untuk pelatihan yang sesuai dengan kebutuhan dalam perawatan pasien. Terdapat ketidakpuasan perawat terhadap kebijakan baru oleh manajemen rumah sakit terkait dengan pemberian kesempatan untuk melanjutkan pendidikan, yaitu karena sudah tidak adanya kebijakan mengenai pemberian pembiayaan untuk melanjutkan pendidikan ke jenjang yang lebih tinggi untuk perawat. Semua perawat merasa senang terhadap kebijakan manajemen RS terkait dengan pemberian penghargaan kepada karyawan. Penghargaan diberikan kepada karyawan yang sudah lama bekerja di RS, yang teladan dan berprestasi, penghargaan diberikan setiap milad RS berupa uang, kenaikan gaji dan sertifikat. Masih ada ketidakpuasan terkait kebijakan pemberian promosi kepada karyawan, karena dirasa prosedur pemberian promosi ke

Tabel 6. Rangkuman Hasil Wawancara Tentang Variabel Relatedness Terhadap Perawat Ruang Rawat Inap di RS PKU Muhammadiyah Yogyakarta Unit II

\begin{tabular}{|c|c|}
\hline $\begin{array}{l}\text { Kata kunci } \\
\text { pertanyaan }\end{array}$ & Coding \\
\hline $\begin{array}{l}\text { Variabel } \\
\text { Relatedness }\end{array}$ & $\begin{array}{l}\text { Hubungan dengan rekan kerja baik, jika ada masalah hanya masalah kecil dan sejauh ini dapat } \\
\text { diselesaikan. } \\
\text { Kebersamaan dan kekeluargaan antar karyawan di RS PKU, saling toleran dan menghormati. } \\
\text { Terjalin hubungan kekeluargaan dan saling mendukung antar rekan kerja, jika ada masalah diselesaikan } \\
\text { bersama. } \\
\text { Saling kerja sama dan kolaborasi antar rekan. } \\
\text { Komunikasi dengan atasan dan dokter baik dan belum pernah ada masalah. } \\
\text { Jika ada masalah diselesaikan bersama-sama dengan direksi setiap rapat hari selasa dan rapat kecil } \\
\text { yang diadakan setiap bulan sekali di ruangan yang dipimpin oleh kepala ruang. }\end{array}$ \\
\hline
\end{tabular}

Sumber: Data Primer Tahun 2014 


\begin{tabular}{|c|c|}
\hline $\begin{array}{l}\text { Kata kunci } \\
\text { pertanyaan }\end{array}$ & Coding \\
\hline Variabel Growth & $\begin{array}{l}\text { Adanya pengadaan pelatihan. } \\
\text { Pelatihan yang diberikan sesuai kebutuhan perawat dan peserta pelatihan juga bergantian. } \\
\text { Kurang puas terhadap kebijakan baru manajemen RS terkait dengan pemberian kesempatan untuk } \\
\text { melanjutkan pendidikan yang sudah tidak membiayai lagi perawat yang hendak melanjutkan pendidikan } \\
\text { yang lebih tinggi, karena di rasa RS SDM untuk jenjang pendidikan yang dibutuhkan sudah memadai, } \\
\text { umpama tidak pun RS tidak menyekolahkan perawat lagi, tetapi akan melakukan perekrutan terkait } \\
\text { SDM yang dibutuhkan RS. } \\
\text { Adanya pemberian penghargaan, biasanya diberikan pada saat milad RS, penghargaan untuk lama } \\
\text { bekerja, berupa uang, kenaikan jabatan dan sertifikat, kenaikan gaji berkala. } \\
\text { Dirasa prosedur pemberian promosi ke karyawan belum transparan dan prosedural karena pemilihan } \\
\text { karyawan yang akan mendapat promosi masih secara subjektif dari direksi saja, belum secara objektif, } \\
\text { yang berarti prosedurnya juga belum terarah dan transparan. }\end{array}$ \\
\hline
\end{tabular}

Sumber: Data Primer Tahun 2014

karyawan belum transparan dan prosedural, karena pemilihan karyawan yang akan mendapat promosi masih secara subjektif dari direksi saja, belum secara objektif, yang berarti prosedurnya juga belum terarah dan transparan. Sehinga masih ada perawat yang tidak tahu mengenai kebijakan tersebut.

Aspek promosi, diungkapkan oleh Anoraga bahwa promosi dan perkembangan diri karyawan yang sejalan dengan perkembangan perusahaan memiliki pengaruh terhadap produktivitas kerja, yang merupakan dampak dari rasa bangga yang ditimbulkan pada diri karyawan(22). Didukung dengan penelitian Handoko yang hasilnya adalah bahwa pengakuan status dengan melibatkan karyawan dalam kegiatan-kegiatan organisasi justru akan meningkatkan produktifitas kerjanya(21).

Terkait kebijakan promosi dan penghargaan, Hasibuan menyatakan bahwa pemberian penghargaan dan promosi dapat meningkatkan ikatan kerja sama, kepuasan kerja, pengadaaan efektif, motivasi, stabilisasi dan disiplin karyawan(23). Dari pendapat tersebut, bahwa pentingnya diketahui kebijakan mengenai promosi dan penghargan kepada karyawan, sebagai motivasi dalam bekerja untuk mencapai kepuasan kerja yang diharapkan, yaitu berupa mendapat promosi ataupun penghargaan dari atasan. Hal ini sesuai dengan penelitian terdahulu oleh Ewika yang menyatakan faktor penghargaan karir mempengaruhi motivasi kerja perawat secara signifikan. Melalui penghargaan yang sesuai dengan apa yang telah dikerjakan merupakan salah satu stimulant yang dapat memotivasi perawat untuk bekerja dengan lebih giat dan lebih baik lagi(24).

\section{SIMPULAN DAN SARAN}

Tingkat motivasi kerja tenaga keperawatan di ruang rawat inap RS PKU Muhammadiyah unit II Yogyakarta ditinjau dari variabel relatedness/ kebutuhan keterkaitan/hubungan, menunjukkan bahwa sebagian besar tingkat motivasi kerja perawat adalah tinggi yaitu sebanyak 48 perawat dengan persentase $94,10 \%$ dan 3 orang perawat atau 5,90\% perawat dengan tingkat motivasi rendah. Jika ada masalah diselesaikan secepatnya dan bersama-sama.

Saran dalam mengoptimalkan motivasi kerja tenaga keperawatan perlu dukungan baik moril dan materiil dan seluruh direksi RS PKU Muhammadiyah Yogyakarta Unit II.

\section{RUJUKAN}

1. Winardi. Psikologi Industri dan Organisasi, Dalam Suatu Bidang Gerak Psikologis Sumber Daya Manusia. Cetakan Ketiga. Kencana Prenada Media Group: Jakarta; 2005.

2. Astiwi R. Pengaruh Fungsi Manajerial, Gaya Kepemimpinan dan Kemampuan Berkomunikasi Kepala Ruang Terhadap Kinerja Perawat di Ruang Rawat Inap RSUD Kota Yogyakarta. J MMR; 2011.

3. Suarli. Manajemen Keperawatan dengan pendekatan praktis. Jakarta: Erlangga; 2010.

4. As'ad M. Seri IImu Sumber Daya Manusia: Psikologi Kerja. Yogyakarta: Liberty; 2008.

5. Hasibuan M. Manajemen Sumber Daya Manusia. Jakarta: Bumi Aksara; 2012.

6. Clayton A. An Empirical Test of a New Theory of Human Needs. Organizational Behavior and Human Performance, Vol. 4.1969. Dalam: Mulder L. Motivation Cycles. Boise State University; 2007.

7. Ruswanti E. Aplikasi Teori Kebutuhan ERGAlderfer Terhadap Motivasi Karyawan Rumah Sakit Islam Hidayatullah Yogyakarta [Tesis]. Jakarta: Universitas Esa Unggul; 2013.

8. Yusman. Hubungan Motivasi Kerja dengan Kepuasan Kerja Perawat di RSUD Djojonegoro Kabupaten Temanggung; 2008. 
9. Thoha M. Perilaku Organisasi: Konsep Dasar dan Aplikasinya, 1st ed. Cetakan 15. Jakarta: PT.Raja Grafindo Persada; 2004.

10. Wijono D. Manajemen Mutu Pelayanan Kesehatan Teori Strategi dan Aplikasi. Surabaya. Airlangga University Press. 2005;1.

11. Ewika. Pengaruh Pelaksanaan MPKP Terhadap Motivasi Kerja Perawat di RSUD Panembahan Senopati Bantul. Universitas Muhammadiyah Yogyakarta; 2014.

12. Wijono S. Kepuasan dan Stres kerja. Salatiga: Widya sari; 2007.

13. Aditama TY. Manajemen Administrasi Rumah Sakit. Jakarta: UI-Pres; 2010.

14. Fauzi. Gambaran Kepuasan Perawat di Unit Rawat Inap RS MH Thamrin Internasional Jakarta. Jakarta: Universitas Indonesia; 2010.

15. Houston. Dasar-Dasar Manajemen Keuangan Buku I. 11th ed. Jakarta: Salemba Empat; 2010.

16. Perdana. Hubungan antara Motivasi dengan Kepuasan Kerja Perawat di RS Marga Husada Kabupaten Wonogiri. Surakarta: Universitas Muhammadiyah Surakarta; 2014.
17. Winardi. Manajemen Perilaku Organisasi. Jakarta: Pranada Media; 2005.

18. Masroor. Level of Job Satisfaction and Intention to Leave among Malaysian Nurses. Business Intelligence Journal. 2010;3(1).

19. Budiman. Analisis Pengaruh Motivasi dan Budaya Organisasi terhadap Kinerja Karyawan. J Manajemen dan Bisnis Sriwijaya. 2009;12(1).

20. Herzberg. Dasar-Dasar Manajemen. 2nd ed. Hasibuan MSP, translator. Jakarta: Bumi Aksara; 2003.

21. Handoko T. Manajemen Personalia dan Sumber Daya Manusia. Yogyakarta: BPFE-Yogyakarta; 2012.

22. Anoraga. Psikologi Kerja. Jakarta: PT Rineka Cipta; 2009.

23. Hasibuan SP, Malayu H. Manajemen Sumber Daya Manusia. 7th rev ed. Jakarta: PT. Bumi Aksara; 2005.

24. Ewika. Pengaruh Pelaksanaan MPKP Terhadap Motivasi Kerja Perawat di RSUD Panembahan Senopati Bantul. Universitas Muhammadiyah Yogyakarta. Yogyakarta; 2014. 